Cite this article: Brezghunova O.O., Sinna O.I. The breeding distribution and numbers of the Jackdaw (Corvus monedula) in Kharkiv City, Ukraine. The Journal of V. N. Karazin Kharkiv National University, Series "Biology", 2020, $35,82-88$.

UDC: 598.293 .1

\title{
The breeding distribution and numbers of the Jackdaw (Corvus monedula) in Kharkiv City, Ukraine O.O. Brezghunova, O.I. Sinna
}

The counts of breeding Jackdaws were made in Kharkiv City, Ukraine in April - early June of 2016-2017. We estimated the breeding density among different habitat types. For such a purpose the city area was divided into $0.25 \mathrm{~km}^{2}$ squares $(n=1354)$ and we estimated the numbers of pairs within the boundaries of 40 squares (QGIS program was used to choose randomly these squares). The surveys were made in April-May (19 squares) and early June (4 squares) in 2016 and April-May (10 squares) and early June (7 squares) in 2017 . The surveys were made within main habitat types such as area of residential blocks of flats, residential area (1-2-storey buildings), industrial area, forest zone, park zone and undeveloped urban areas. The data on the area occupied by every major habitat type (in $\mathrm{km}^{2}$ ) were calculated by QGIS program. The $90 \%$ of the territory of Kharkiv City was analysed, except water reservoirs and traffic way areas. The data of the surveys were extrapolated across areas of the same habitat types. Also we have searched for Jackdaw colonies within the boundaries of Kharkiv City to take these data into account. According to the collected data the Jackdaw prefers to nest in crevices of old 3-5-level buildings at built-up districts or in round cross-sections of posts at blocks-of-flats areas. Thus the mean density here was 22 pairs $/ \mathrm{km}^{2}$. The mean density of Jackdaw in industrial areas was 15 pairs $/ \mathrm{km}^{2}$, in undeveloped urban areas - 1.2 pairs $/ \mathrm{km}^{2}$, and in residential area (1-2-storey buildings) -0.7 pairs $/ \mathrm{km}^{2}$. The total number of breeding Jackdaws in Kharkiv City was estimated at 2325 to 2630 pairs. The mean density of Jackdaws was 7.5 pairs $/ \mathrm{km}^{2}$. Taking into account the moderate decline in the population of the Jackdaws in some European countries (although in general the population trend remains stable within the continent), and the lack of the surveys of the breeding distribution and numbers of Jackdaws in large cities of the Eastern Ukraine, it's reasonable to use our data as an optimal starting point for the monitoring of the regional population trend of the species. The data of 2016 year survey were used in European Breeding Bird Atlas 2 (EBBA2) programme (square 37UCR2).

Key words: Jackdaw (Corvus monedula), breeding density.

About the authors:

O.O. Brezghunova - V.N. Karazin Kharkiv National University, Svobody Sq., 4, Kharkiv, Ukraine, 61022, olgabresgunova@gmail.com, https://orcid.org/0000-0002-7503-2790

O.I. Sinna - V.N. Karazin Kharkiv National University, Svobody Sq., 4, Kharkiv, Ukraine, 61022, o.sinna@physgeo.com, http://orcid.org/0000-0002-7693-7348

\section{Introduction}

The Jackdaw (Corvus monedula) is a common and widely distributed species in Kharkiv City, Ukraine. More than 120 years ago in Kharkiv region the Jackdaws nested in niches, holes, crevices of buildings especially under roofs, in attics, in brick chimneys, church towers (Somov, 1897) as they do today. The tree-hole nesting (in hollow trees) was quite common at the end of $19^{\text {th }}$ century but is not recorded in Kharkiv City and neighboring areas nowadays though more than 50 years ago the Jackdaws formed colonies and nested in tree cavities in oak forest at approximately $90 \mathrm{~km}$ from Kharkiv City (Novikov et al., 1963). Also the Jackdaws nested in niches and holes in loessial and more rarely granite slopes (holes in cliffs) in some parts of Mykolayiv, Vinnytsya and Zhytomyr regions of Ukraine until 1990 (Loparev, Yanish, 2010).

The Jackdaw was once assigned to a group of species with high tolerance to climate change based on the results of the analysis of life history traits e.g. trophic niche, number of brood attempts per year, life expectancy and others (Banik, Atemasov, 2010) thus presuming that the species may be at least less vulnerable to climatic fluctuations. The population trends for the Jackdaw in some European countries e.g. in the Czech Republic, Hungary, Slovenia are declining but are stable or even increasing in the others as in Finland, Sweden, the United Kingdom, Belgium (Božič, 2016; Wild Bird Populations..., 2018). Moreover, the population trends can be different among regions and habitats. Thus, for example, the increase in farmland and the decrease in woodland habitats were observed in the United Kingdom (Common Birds Census 1964-1993; Gregory, Marchant, 1996). In Ukraine the woodland population tends to decrease during last 35 years (Senik, Gorban, 2015) and nesting in steep holes is not noticed anymore (Loparev, Yanish, 2010). The oppositely directed population trends are evident in different 
regions of Ukraine. Thus, the numbers of breeding Jackdaws decreased at the begining of $21^{\text {st }}$ century in Western Ukraine (Horban, 2002; Senik, Gorban, 2015; Bokotey et al., 2010), but apparently increased in the same years in some cities of Eastern Ukraine (M.V. Banik, unpubl. data). Besides, a slight increase of breeding population of the Jackdaws was observed in 2004-2008 years in Sumy, Vinnytsya, Kyiv and Cherkasy regions (Loparev, Yanish, 2010; Yanish, 2015).

Meanwhile, the data on the Jackdaw from the PECBMS (The Pan-European Common Bird Monitoring Scheme) demonstrate that the population slightly increased in 18 European countries from 1966 to 2002 (Vorisek et al., 2008). The data of both Birdlife International and the PECBMS show that European population of the Jackdaws slightly decreased from 1980 to 2009 (Inger et al., 2014). In general the population trend remains stable (BirdLife International..., 2020).

According to prior survey we counted up to 3500 Jackdaws along with more than 60000 of Rooks (C. frugilegus) outside the breeding season and in winter time at traditional communal roosting sites in Kharkiv City (Bresgunova, 2009).

The aim of the current study is to estimate reliably the numbers of the breeding population of Jackdaws and peculiar aspects of its distribution in Kharkiv City. This attempt may serve as a starting point for the monitoring of the regional population trend.

\section{Method}

The counts of the numbers of Jackdaws were carried out in Kharkiv City, Ukraine, in 2016-2017 with the main purpose to estimate the breeding density, Kharkiv population size and the distribution across different habitat types. The city area was divided into $0.25 \mathrm{~km}^{2}$ squares $(n=1354)$. QGIS program was used to choose randomly 40 squares where the numbers of nesting birds were then counted and mapped (Fig. 1). We could not accommodate stratified sampling scheme because it required more counts efforts within industrial areas where in most cases special permissions are needed to work. The surveys were made in April-May (19 squares) and early June (4 squares) in 2016 and April-May (10 squares) and early June (7 squares) in 2017. Thus the time span of the surveys (April to early June) coincided with the Jackdaw breeding period (see also Cramp, Perrins, 1994; Podobivskyi, Kotiv, 2016). We accomplished a distribution study with use of single species count method (Bibby et al., 1993; Czechowski et al., 2013).

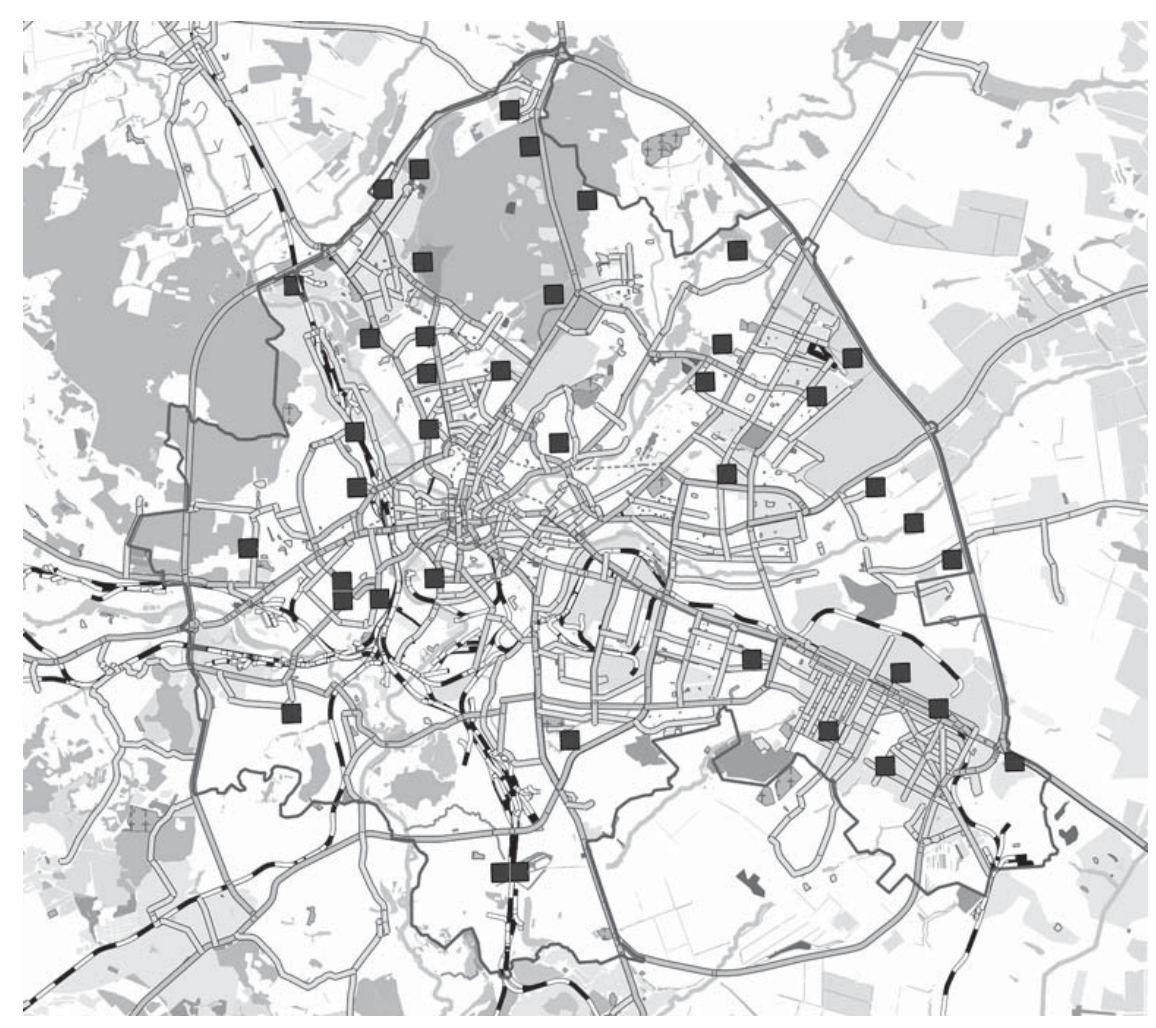

Fig. 1. The distribution of squares surveyed in Kharkiv City 
Then we determined the numbers of nesting birds by extrapolating the collected data for the main habitat types e.g. area of residential blocks of flats, residential area (1-2-storey buildings), industrial area, forest zone, park zone and undeveloped urban areas. The data on the area occupied by every major habitat type (in $\mathrm{km}^{2}$ ) were calculated by QGIS program. Thus $90 \%$ of the territory of Kharkiv City was analysed, except water reservoirs and traffic way areas. This calculation was confirmed with the vector data gathered at the beginning of 2000's. Moreover, we conducted an additional survey in search of all Jackdaw colonies within the boundaries of Kharkiv City in 2016-2017 to take into account the most numerous colonies. The data of 2016 year survey were used in European Breeding Bird Atlas 2 (EBBA2) programme (square 37UCR2).

Descriptive statistics were used in the analysis of the data on the breeding density of Jackdaw (Gould et al., 2020). Confidence intervals were calculated with application of bootstrap procedure (100 000 resamples) with use of Statistics101 vers. 5.2. (Grosberg, 2020).

Results: breeding density and population size

The data on the breeding density of Jackdaws are summarized in Table 1. The species prefers to nest at suitable cavities such as wall holes, crevices, chimneys, ruined buildings and ventilation system in old 3-5-level buildings at built-up districts or in round cross-sections of posts and poles at residential blocks of flats areas where the mean density was 22 pairs $/ \mathrm{km}^{2}$. In industrial areas the mean density of Jackdaw was 15 pairs $/ \mathrm{km}^{2}$. At undeveloped urban areas several pairs can use adjacent poles for nesting.

Table 1. The breeding density of the Jackdaw (Corvus monedula) within the borders of Kharkiv City (summarized data of counts in squares $0.25 \mathrm{~km}^{2}$ )

\begin{tabular}{|c|c|c|c|c|c|}
\hline Habitat type & $\begin{array}{c}\text { Total } \\
\text { number } \\
\text { of } \\
\text { squares }\end{array}$ & $\begin{array}{c}\text { Mean density } \\
\text { per square } \\
\text { (pairs } / 0.25 \mathrm{~km}^{2} \text { ) } \\
\pm \text { std. err. of } \\
\text { mean }\end{array}$ & $\begin{array}{c}\text { Mean } \\
\text { density } \\
\left(\text { pairs } / \mathrm{km}^{2}\right)\end{array}$ & $\begin{array}{c}\text { Limits of } \\
\text { variation of } \\
\text { mean density } \\
\text { per square } \\
(\text { pairs/ } \\
\left.0.25 \mathrm{~km}^{2}\right)\end{array}$ & $95 \% \mathrm{Cl}$ \\
\hline Blocks of flats areas & 10 & $5.5 \pm 2.1$ & 22 & $0-16$ & 1.80 to 9.70 \\
\hline $\begin{array}{l}\text { Residential area (1-2- } \\
\text { storey buildings) }\end{array}$ & 11 & $0.18 \pm 0.18$ & 0.7 & $0-2$ & 0 to 0.55 \\
\hline Industrial areas & 4 & $3.75 \pm 3.75$ & 15 & $0-15$ & * \\
\hline Undeveloped urban areas & 10 & $0.3 \pm 0.3$ & 1.2 & $0-3$ & 0 to 0.90 \\
\hline Forests and woodlands & 4 & 0 & 0 & 0 & * \\
\hline Park zone & 1 & 0 & 0 & 0 & * \\
\hline $\begin{array}{l}\text { Total (within the borders of } \\
\text { Kharkiv City) }\end{array}$ & 40 & $1.875 \pm 0.72$ & 7.5 & $0-16$ & 0.63 to 3.40 \\
\hline
\end{tabular}

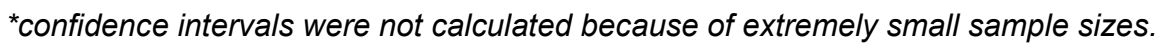

Table 2. The estimates for the number of breeding Jackdaw pairs for different habitat types in Kharkiv City

\begin{tabular}{|c|c|c|}
\hline Habitat type & Habitat area, $\mathrm{km}^{2}$ & Number of pairs \\
\hline $\begin{array}{l}\text { Residential area } \\
\text { (1-2-storey buildings) }\end{array}$ & 54.5 & 38 \\
\hline Blocks of flats areas & 64.26 & 1413 \\
\hline Industrial areas & 51.66 & 775 \\
\hline Undeveloped urban areas & 82.53 & 99 \\
\hline Park zone & 21.42 & 0 \\
\hline Forests and woodlands & 40.64 & 0 \\
\hline Total & 315 & 2325 \\
\hline
\end{tabular}


The total size of the breeding population of Jackdaw within the borders of Kharkiv City was estimated based on the calculated areas of major habitat types. The total number of breeding Jackdaws was estimated at 2325 pairs (see Table 2 for the details).

The Jackdaws form not only loose settlements with the maximum number of 16 pairs per square (Table 1) but more numerous and dense colonies in Kharkiv City (Table 3). One colony which comprises 150-160 pairs is located in old buildings of Kharkiv Tile Plant and another one is situated at main building of V.N. Karazin Kharkiv National University in city centre. Taking into account these data, the overall estimate for the size of breeding population of Jackdaw in Kharkiv City may be corrected to 2630 pairs.

Table 3. Main colonies of Jackdaw within the borders of Kharkiv City (where the general numbers are more than 30 breeding pairs*)

\begin{tabular}{|l|c|c|}
\hline Location & Number of pairs & Nesting sites \\
\hline Kharkiv Tile Plant & 160 & $\begin{array}{c}\text { Holes and niches in buildings' } \\
\text { walls }\end{array}$ \\
\hline $\begin{array}{l}\text { Main building of V.N. Karazin Kharkiv National } \\
\text { University and adjacent structures/buildings }\end{array}$ & 70 & $\begin{array}{c}\text { Holes and niches in buildings' } \\
\text { walls }\end{array}$ \\
\hline Central city market (bazaar) & 45 & $\begin{array}{c}\text { Holes and niches in buildings' } \\
\text { walls }\end{array}$ \\
\hline Saburova dacha (Complex of medical buildings) & 40 & $\begin{array}{c}\text { Holes and niches in buildings' } \\
\text { walls }\end{array}$ \\
\hline
\end{tabular}

*if the distance between neighbouring nests within a settlement was up to $60 \mathrm{~m}$ it was considered a colony.

\section{Discussion: population size and suitable habitats}

Our data suggest that the numbers of breeding population of Jackdaw within the borders of Kharkiv City (roughly an area of $350 \mathrm{~km}^{2}$ ) are about 2325-2630 pairs. Unfortunately, a few published data on other Ukrainian cities exist. But, for comparison, only 176 pairs of Jackdaws nest in Khmelnytsky city with an area of $86.2 \mathrm{~km}^{2}$ (Iljinsky, 2009). In Khmelnytsky almost all colonies are located at built-up districts with old 4-5-level buildings with mean density of 26.5 pairs $/ \mathrm{km}^{2}$ (Iljinsky, 2009). The similar mean density of 22 pairs $/ \mathrm{km}^{2}$ is observed in present study for Kharkiv's residential blocks of flats areas. In some residential quarters of Lviv City the general breeding density of Jackdaw are 18.8 pairs $/ \mathrm{km}^{2}($ Senik, Kasparova, 2012).

This study shows that the Jackdaw uses only urban habitats in Kharkiv City. Generally in Ukraine, the Jackdaw typically nests in urban areas (Nadtochiy, Ziomenko, 2001; Bashta, 2003). Indeed the most important factor for Jackdaws' survival is an availability of suitable nest cavities (Salvati, 2002; Bochenski, Czechowski, 2005; Iljinsky, 2009), thus renovation of old buildings with an aim of thermal insulation can lead to the decline in numbers or even to local extinction (Czechowski et al., 2013; Božič, 2016). For example, in Khmelnytsky city (Ukraine) the Jackdaws nest only in building's niches and crevices and prefer the old ones (Iljinsky, 2009, 2012). Our findings highlight the fact that the Jackdaws in Kharkiv City are most numerous at built-up districts and industrial areas where they have an opportunity to nest in cavities of old buildings. It may be supposed that the reconstruction of old and relatively newish buildings during the last decade will have an adverse effect on the Jackdaws because they have to face with a lack of suitable nest sites.

The Jackdaws also can nest in hollow round cross-sections of posts and poles in Kharkiv City as well as in other Ukrainian regions (Nadtochiy, Ziomenko, 2001; Loparev, Yanish, 2010; Senik, Gorban, 2015). All the above mentioned certainly doesn't mean that the Jackdaw is indeed a well-urban-adapted species in Europe. One recent study has demonstrated that a lack of high-quality food especially during breeding period may limit breeding success in this species (Meyrier et al., 2017). The decreases in population of the Jackdaw can be attributed to a decrease in a food supply (Tiainen, 1985). Thus, the distance between breeding and foraging sites plays an important role for the Jackdaw survival (Bochenski, Czechowski, 2005; Iljinsky, 2009). In Kharkiv City the species is not only practising the searches for people's leftovers from dustbins but also prefers to forage in flood-plain areas, in park zone, and on agricultural fields situated nearby to the city boundaries. Namely, the largest colonies of western parts of Kharkiv City are found in close proximity to the suitable foraging sites. 
The two biggest colonies of the Jackdaws in Kharkiv City (the first and the second in Table 3) are associated and located near the rookeries. These two species, the Rook and the Jackdaw, are very similar in their feeding habitat preferences in breeding time (Yanish, 2012). Individuals of both species participate in formation of mixed flocks including foraging groups and communal roosts (Bresgunova, 2009). In other parts of Ukraine such as Vinnytsya Region, south of Zhytomyr region and south-west of Kyiv Region, and Lviv City (Western Ukraine) the Rooks and Jackdaws often nest together (Loparev, Yanish, 2010; Senik, Kasparova, 2012). Moreover, the Rooks seem to appear and build their nests in such colonies early than Jackdaws (Senik, Gorban, 2015). Such a habit when the both species tend to nest together has been observed also in other European and Asian countries (Gavrin, 1974; Cramp, Perrins, 1994; Repin, 2012).

We recommend the use of our survey scheme to monitor the state of the breeding population of Jackdaw in Kharkiv City in the future and especially to track the trends in different habitat types.

\section{Acknowledgements}

We are very grateful to A. Atemasov and M. Banik for their assistance in the starting stages of the current research.

\section{References}

Banik M.V., Atemasov A.A. (2010). An attempt to assess the vulnerability of breeding birds of Ukraine to climate change. Branta, 13, 9-20. (in Russian)

Bashta A.-T.V. (2003). The general survey of nesting birds of flood-plain forests of Borzshava river valley: preliminary results. Priority of ornithological research. VIII conf. of ornithologists of Western Ukraine. P. 97-99. (in Ukrainian)

Bibby C.J., Burgess N.D., Hill D.A. (1993). Bird census techniques. Academic Press. $3^{\text {rd }}$ printing. 257 p. BirdLife International. (2020). Species factsheet: Corvus monedula. IUCN Red List for birds. Downloaded from http://www.birdlife.org on 05/02/2020

Bochenski M., Czechowski P. (2005). Kawka Corvus monedula w Zielonej Gorze: rozmieszczenie i liczebnosc. Ptaki krukowate Polski. Corvids of Poland (ed. L. Jerzak, B.P. Kavanagh, P. Tryjanowski). Poznan: Bogucki Wyd. Nauk. P. 531-539.

Bokotey A.A., Dzyubenko N.V., Gorban I.M. et al. (2010). Breeding avifauna of the Upper Dnister basin. Lviv. 400 p. (in Ukrainian)

Božič L. (2016). Numbers, distribution and nest site characteristics of Jackdaw Corvus monedula in Slovenia and its conservation status. Acrocephalus, 37(170/171), 123-150. https://doi.org/10.1515/acro2016-0007

Bresgunova O.A. (2009). Organization of Rooks (Corvus frugilegus L.) and Jackdaws' (C. monedula L.) communal roosts in Kharkiv City, Ukraine. The conference dedicated to the memory of 80 years of prof. A.P. Krapivniy's birth. Conference's materials. Kharkiv. P. 21-26. (in Russian)

Cramp S., Perrins C.M. (eds.). (1994). The Birds of the Western Palearctic: Handbook of the Birds of Europe, the Middle East, and North Africa. Vol. VIII. Crows to Finches. Oxford: Oxford University Press. $956 \mathrm{p}$.

Czechowski P., Bocheński M., Ciebiera O. (2013). Decline of Jackdaws Corvus monedula in the city of Zielona Góra. Intern. Stud. Sparrows, 37, 32-36. https://doi.org/10.1515/isspar-2015-0023

Gavrin V.F. (1974). Family Corvidae. Birds of Kazahstan (ed. A.F. Kovshar). Vol. V. Alma-Ata. P. 41-120. (in Russian)

Gould R., Wong R., Ryan C. (2020). Introductory Statistics: Exploring the world through data. $3^{\text {rd }}$ ed. Pearson. $800 \mathrm{p}$.

Gregory R.D., Marchant J.H. (1996). Population trends of Jays, Magpies, Jackdaws and Carrion Crows in the United Kingdom. Bird Study, 43(1), 28-37. https://doi.org/10.1080/00063659609460993

Grosberg J. (2020). Statistics101. vers.5.2. [Computer software]. Retrieved October 17, 2020 from http:// www.statistics101.net/index.htm

Horban I. (2002). Rare and disappearing species of birds of Shatsk National park. Visnyk of L'viv univ. Biology Series, 29, 127-137. (in Ukrainian)

llijinsky S.V. (2009). The spread and spatial distribution of Jackdaw Corvus monedula settlement in Khmelnytsky during nested period. Selected research works H.S. Skovoroda Kharkiv National Pedagogical University. Biology Series, 11, 36-42. (in Ukrainian) 
llijinsky S.V. (2012). The adaptation of corvid birds to urban environment during breeding period. X conf. Birds of Corvidae family in urban and rural landscapes of Northern Eurasia. Yakornaya Shchel. P. 93-98. (in Russian)

Inger R., Gregory R., Duffy J.P. et al. (2014). Common European birds are declining rapidly while less abundant species' numbers are rising. Ecology Letters, 1-19. https://doi.org/10.1111/ele.12387

Loparev S.O., Yanish Ye.Yu. (2010). The numbers and distribution of Jackdaw (Corvus monedula) in Forest-steppe of Central Ukraine. Corvids of Northern Eurasia: Miscellanea of IX International Research/Practice Conference on Study of Corvids of Northern Eurasia. Ed. V.M. Konstantinov. Omsk. P. 81-84. (in Russian)

Meyrier E., Jenni L., Bötsch Y. et al. (2017). Happy to breed in the city? Urban food resources limit reproductive output in Western Jackdaws. Ecology and Evolution, 7(5), 1363-1374. https://doi.org/10.1002/ece3.2733

Nadtochiy G.S., Ziomenko S.K. (2001). Corvids of Kharkiv City. The actual problems of investigation and protection of birds of Eastern Europe and North Asia. XI ornithological conf. Kazan. P. 461-462. (in Russian)

Novikov G.A., Malchevskiy A.S., Ovchinnikova N.P., Ivanova N.S. (1963). Birds of "The Vorlska forest» ("Les na Vorskle") and neighborhoods. The problems of ecology and synecology, 8 (Ecology of terrestrial vertebrates), 9-118. (in Russian)

Podobivskyi S.S., Kotiv A.W. (2016). Preliminary information about the species composition and peculiarities of biology reproduction of Ternopil synanthropic passerine birds series (Passeriformes). Scientific Herald of Chernivtsi University. Biology (Biological Systems), 8(2), 246-251. (in Ukrainian)

Repin D.V. (2012). Corvidae species in Orenburg region. $X$ conf. Birds of Corvidae family in urban and rural landscapes of Northern Eurasia. Yakornaya Shchel. P. 211-214. (in Russian)

Salvati L. (2002). Nest site and breeding habitat characteristics in urban Jackdaws Corvus monedula in Rome (Italy). Acta Ornithologica, 37(1), 15-19. https://doi.org/10.3161/068.037.0103

Senik M., Gorban I. (2015). The distribution and biology of the Jackdaw in Ukraine. Jackdaw (Corvus monedula L.) in anthropogenic landscapes of Palearctic region. Moscow-Ivanovo. Publishers "Znak". P. 106-125. (in Russian)

Senik M., Kasparova S. (2012). The peculiarities of the distribution and numbers' dynamics of the Jackdaw at winter and spring-summer periods in Lviv City. $X$ conf. Birds of Corvidae family in urban and rural landscapes of Northern Eurasia. Yakornaya Shchel. P. 234-237. (in Russian)

Somov N.N. (1897). Bird fauna of Kharkov government. Kharkiv: Tipographia A. Darre. 689 p. (in Russian)

Tiainen J. (1985). Monitoring bird populations in Finland. Ornis Fennica, 62, 80-89.

Vorisek P., Gregory R.D., van Strien A.J., Mevlina A.G. (2008). Population trends of 48 common terrestrial bird species in Europe: results from the Pan-European Common Bird Monitoring Scheme. Revista Catalana d'Ornitologia, 24, 4-14.

Wild Bird Populations in the UK, 1970 to 2017. (2018). $8^{\text {th }}$ November. Responsible Statistician: Christine Holleran. Department for Environment, food and other affairs. $55 \mathrm{p}$.

Yanish Ye.Yu. (2012). The habitat preference by corvid birds in forest-steppe Ukraine in breeding period. $X$ conf. Birds of Corvidae family in urban and rural landscapes of Northern Eurasia. Yakornaya Shchel. P. 286-289. (in Russian)

Yanish Ye.Yu. (2015). The dynamics of the breeding density of Jackdaw in forest-steppe of Ukraine. Jackdaw (Corvus monedula L.) in anthropogenic landscapes of Palearctic region. Moscow-Ivanovo. Publishers "Znak". P. 125-137. (in Russian)

\section{Розподіл та чисельність галки (Corvus monedula) у гніздовий період на території м. Харкова, Україна О.О. Брезгунова, О.І. Сінна}

Обліки чисельності галки проводили у місті Харкові з квітня до початку червня 2016-2017 рр. Визначали гніздову чисельність у різних типах біотопів. Для цього територія міста була поділена на квадрати 0,25 км² $^{2}$ $(n=1354)$ і у 40 з них проведені обліки (квадрати було обрано випадковим пошуком у програмі QGIS). Oбліки проводили у квітні-травні (19 квадратів) та на початку червня (4 квадрати) 2016 року та у квітні-травні (10 квадратів) та на початку червня (7 квадратів) у 2017 році. Кожен 3 квадратів був віднесений до однієї 3 категорій, а саме, із переважанням багатоповерхової забудови, приватної забудови, промислової зони, лісової зони, паркової зони, пустирів (незабудованих ділянок). Площі кожного біотопу (у км²) були розраховані за 
допомогою програми QGIS для 90 \% території міста (окрім площ водойм та вулиць). Розрахунки загальної чисельності галки здійснювались шляхом екстраполяції середньої чисельності пар у квадратах на всю площу даного типу біотопу у місті Харкові. Окрім того, проводився пошук та моніторинг усіх великих колоній галок у межах міста. Їхня чисельність враховувалась окремо. Галка віддає перевагу гніздуванню у щілинах старих 35-поверхових будинків або у стовпах ЛЕП круглого перетину на ділянках із багатоповерховою забудовою. Середня гніздова чисельність галки на таких ділянках дорівнює 22 пар/км². Щільність населення галки на ділянках із промисловою забудовою становить 15 пар/км², на пустирях та незабудованих ділянках 1,2 пар/км², тоді як у частинах міста із переважанням одно-двоповерхової (приватної) забудови - 0,7 пар/км². Загалом на території міста гніздиться від 2325 до 2630 пар. Середня щільність галки у місті - 7,5 пар/км². Беручи до уваги, що у деяких країнах Європи спостерігається падіння чисельності виду (хоча в цілому тренд на континенті залишається стабільним), та зважаючи на брак даних щодо чисельності галки у період гніздування у містах Східної України, рекомендуємо використовувати отримані дані для подальшого моніторингу чисельності виду. Дані обліків 2016 року використовувалися для програми «Атлас гніздових птахів Європи-2» (ЕВBA2) (квадрат 37UCR2).

Ключові слова: галка (Corvus monedula), гніздова чисельність.

Про авторів:

О.О. Брезгунова - Харківський національний університет імені В.Н. Каразіна, м. Свободи, 4, Харків, Україна, 61022, olgabresgunova@gmail.com, https://orcid.org/0000-0002-7503-2790

О.І. Сінна - Харківський національний університет імені В.Н. Каразіна, м. Свободи, 4, Харків, Україна, 61022, o.sinna@physgeo.com, http://orcid.org/0000-0002-7693-7348

\section{Распределение и численность галки (Corvus monedula) в гнездовой период на территории г. Харькова, Украина О.А. Брезгунова, Е.И. Сенная}

Учеты численности галки проводили в городе Харькове с апреля до начала июня 2016-2017 гг. Определяли гнездовую численность в разных типах биотопов. Для этой цели территория города была разделена на квадраты 0.25 км² $^{2}(n=1354)$ и в 40 из них проведены учеты (квадраты были выбраны случайным образом с помощью программы QGIS). Учеты проводились в апреле-мае (19 квадратов) и в начале июня (4 квадрата) 2016 года, а также в апреле-мае (10 квадратов) и в начале июня (7 квадратов) 2017 года. Квадратам присваивалась одна из категорий, а именно: многоэтажная застройка, частная застройка, промышленная зона, лесная зона, парковая зона, пустыри и другие незастроенные участки. Площади каждого биотопа (в км²) были рассчитаны с помощью программы QGIS для 90 \% территории города (за исключением площадей, занимаемых водоемами, улицами и проспектами). Расчеты общей численности галки осуществлялись методом экстраполяции средней численности в квадратах на площадь, занимаемую данным биотопом в городе. Более того, проводили поиск и мониторинг крупных колоний галок в пределах Харькова и отдельно учитывали полученные данные. Галка предпочитает гнездиться в щелях старых 3-5-этажных зданий или в нишах столбов лЭП круглого сечения на участках с многоэтажной застройкой. Средняя гнездовая численность на таких участках достигает 22 пар/км². Плотность населения вида в районах с промышленной застройкой составляет 15 пар/км², на пустырях и незастроенных участках - 1,2 пар/км², в районах с одно- и двухэтажной застройкой 0,7 пар/км². В целом на территории города гнездится от 2325 до 2630 пар. Средняя плотность гнездования галки в городе 7,5 пар/км². Принимая во внимание то, что в отдельных странах Европы отмечено падение численности вида (хотя в целом тренд на континенте сохраняется стабильным), а также учитывая нехватку данных по численности галки в крупных городах Восточной Украины, рекомендуем использовать полученные данные для дальнейшего мониторинга численности вида. Данные учета численности 2016 года использовались для программы «Атлас гнездящихся птиц Европы-2» (квадрат 37UCR2).

Ключевые слова: галка (Corvus monedula), гнездовая численность.

06 aвmopax:

О.А. Брезгунова - Харьковский национальный университет имени В.Н. Каразина, пл. Свободы, 4, Харьков, Украина, 61022, olgabresgunova@gmail.com, https://orcid.org/0000-0002-7503-2790

Е.И. Сенная - Харьковский национальный университет имени В.Н. Каразина, пл. Свободы, 4, Харьков, Украина, 61022, o.sinna@physgeo.com, http://orcid.org/0000-0002-7693-7348

Подано до редакції / Received: 24.05.2020 